\title{
Effect of Social Suport and Social Interaction on Anxiety Among Pregnant Women
}

\author{
Imelda Dearni Simarmata'), Uki Retno Budihastuti'2), Didik Tamtomo3) \\ 1)Masters Program in Public Health, Universitas Sebelas Maret \\ 2)Department of Obstetrics and Gynecology, Dr. Moewardi Hospital, Surakarta \\ 3)Faculty of Medicine, Universitas Sebelas Maret
}

\begin{abstract}
Background: There is growing evidence that the antenatal period is a time of increased liability to mental disorders. The most common psychiatric illnesses during pregnancy and the postpartum period are depressive and anxiety disorder. The purpose of this study was to examine the effect of social suport and social interaction on anxiety among pregnant women.

Subjects and Method: A cross sectional study was carried out in community heath centers in Kutai Kartanegara, East Kalimantan, from November to December 2018. A sample of 200 pregnant women was selected by simple random sampling. The dependent variable was anxiety. The independent variables were education, parity, stress, family income, family support, social interaction, and conselling. The data were collected by questionnaire and analyzed by a multiple linear regression.

Results: Anxiety among pregnant women increased with stress $(b=0.33 ; 95 \% \mathrm{CI}=0.16$ to 0.49 ; $\mathrm{p}=0.001)$. It was decreased by high education $(\mathrm{b}=-2.37 ; 95 \% \mathrm{CI}=-3.93$ to $-0.81 ; \mathrm{p}=0.003)$, high income $(b=-4.69 ; 95 \% \mathrm{CI}=-7.81$ to $-1.57 ; \mathrm{p}=0.003)$, parity $(\mathrm{b}=0.38 ; 95 \% \mathrm{CI}=-2.98$ to $-0.26 ; \mathrm{p}=$ $0.001)$, strong family support $(b=-0.38 ; 95 \% C I=0.52$ to $0.24 ; p=0.001)$, social interaction $(b=-$ $0.27 ; 95 \% \mathrm{CI}=-0.42$ to $-0.12 ; \mathrm{p}=0.001)$, and conselling $(\mathrm{b}=-0.91 ; 95 \% \mathrm{CI}=-1.77$ to $-0.05 ; \mathrm{p}=$ $0.004)$.
\end{abstract}

Conclusion: Anxiety among pregnant women increases with stress. It is decreased by high education, high income, parity, strong family support, social interaction, and conselling.

Keywords: anxiety, stress,social interaction, pregnant women

\section{Correspondence:}

Imelda Dearni Simarmata. Masters Program in Public Health,UniversitasSebelas Maret, Jl. Ir. Sutami 36A, Surakarta 57126, Central Java, Indonesia. Email: imeldadearni1888@gmail.com. Mobile: 081227657035

\section{BACKGROUND}

Pregnancy is a natural process and women should definitely crave this process in their lives. However, not all pregnant women enjoy the pregnancy process. During pregnancy, women generally experience physical and psychological changes that appear to be related to biological (hormonal) changes that are experienced. Of course this will result in psychological problems for pregnant women if they are not managed properly (Mansur and Budiarti, 2014). Psychologically, pregnant women will usually experience psychological disorders, one of which is anxiety
(Walyani, 2017). Anxiety is a condition when individuals feel anxiety or anxiety, and uncontrolled discomfort about the possibility of something bad happening (Halgin and Whitebourne, 2010). Anxiety for pregnant women can arise because of the long time when waiting for birth full of uncertainty and also the shadow of things that are frightening during labor. The psychological burden on a pregnant woman is more common in the third trimester of pregnancy than in the first and second trimesters (Rafael, 2015).

The results of the study show the high prevalence of psychiatric illness in pregnancy. 
Estimates of the prevalence of depression and antenatal anxiety vary (Waqas et al., 2015). A study in rural Bangladesh in 2011 estimated the prevalence of depression in pregnant women by $18 \%$ and $29 \%$ for anxiety in pregnant women (Nasreen et al., 2011). Study in Hong Kong in first to third trimester pregnant women was 54\% experiencing anxiety and $37 \%$ experiencing depressive symptoms (Madhavanprabhakaran et al., 2015). Study on anxiety was also carried out in Pakistan, of 165 pregnant women and 70\% experienced anxiety and depression (Chan et al., 2013). Riskesdas data in 2013, the prevalence of mental emotional disorders (symptoms of depression and anxiety) amounts to $6 \%$. This means that more than 14 million people suffer from mental emotional disorders in Indonesia (Indonesian Ministry of Health, 2013). In Indonesia, there are 107,000 (28.7\%) pregnant women who experience anxiety in facing labor (Mandagi, 2013). This is in accordance with the Indonesian Health Demographic Survey (IDHS) in 2013 which explained that hypertension was $27.1 \%$ and others (such as congenital diseases in mothers before pregnancy including anxiety).

High anxiety experienced by pregnant women not only endangers the fetus but also the mother, these hazards include the release of stress hormones and rising blood pressure. The increase in blood pressure can lead to imperfect fetal growth and even maternal and infant death (Helbig et al., 2013). High anxiety can also cause low birth weight (LBW), premature birth, hyperactivity and irritability (Pieter and Lubis, 2010). In some studies, it is also found that anxiety can cause physicological problems during childbirth such as prolonged labor or tearing of the baby's exit. Prolonged labor and elevated blood pressure then become one of the causes of high MMR (Maternal Mortality Rate) in Indonesia.

According to Indonesia's health profile data for 2015 the Maternal Mortality Rate in Indonesia is $305 / 100,000$ live births. For the Maternal Mortality Rate in Kutai Karta- negara Regency is still quite high, based on health profile data of the Kutai Kartanegara Regency itself in 2015 the health indicator achievement for MMR (Maternal Mortality) was 216 per 100,000 live births and increased in 2016 to 242 per 100,000 live births. In 2016, the highest number of maternal deaths in Kutai Kertanegara District was in East Kaliamantan Province, which amounted to 32 cases consisting of 10 maternal deaths, 6 maternal deaths and 16 postpartum maternal deaths. The biggest case that causes maternal death is eclampsia and other diseases that are not direct causes (Kukar Health Office, 2017).

Based on study conducted by Waqas et al., 2015, the factors that can influence the anxiety of pregnant women are lack of financial preparation that can cause concern about the cost of labor and the cost of baby care. In addition, family support is one of the psychological needs of a mother who is very much needed, and family support can increase self-confidence in the mother before labor so that it can reduce anxiety and reduce feelings of pain in labor. This is in accordance with the study conducted (Rayment-Jones et al., 2017).

Based on the description above, the studyers are interested in conducting a study entitled "The Effect of Social Support and Social Interaction on Anxiety among Pregnant Woman".

\section{SUBJECTS AND METHOD \\ 1. Study Design}

This was an analytic observation with a cross sectional study design. The study was conducted in the working area of East Kalimantan Kutai Kartanegara District Health Center, Indonesia in November 2018 until December 2018.

\section{Population and Samples}

The target population in this study consists of pregnant women who were examined at the health center in the area of Kutai Kartanegara Regency in 2018 while the source populations 
of this study were trimester III pregnant women. The sampling is done using simple random sampling technique.

\section{Study Variables}

The dependent variable was anxiety. The independent variables were education, gravida, employment status, family support, family income, psychological stress, social interaction and counseling.

\section{Operational Definition of Variables}

Anxiety was a feeling of anxiety, worry and tension that afflicts the respondent who is preparing for labor with the HRS-A questionnaire.

Education was a learning process that has been taken until graduating through formal education.Family income is a condition that describes the income of husband and wife obtained through work that is calculated using the average income of the last 6 months before the data collection.

Gravida was the number of pregnancies that a mother has ever experienced. The most important thing to note is how many times the mother is pregnant, not the number of babies born.

Family support was support from the husband / parent / sibling in the form of helping or giving attention to the study subjects.

Stress was a negative emotional condition experienced by pregnant women such as feeling restless, irritable and overreacting to situations where measurement with the Perceived Stress Scale (PSS) Questionnaire.

Social interaction was an interrelated relationship between individuals, social groups, and society.Counseling was the process of providing information carried out through interviews by an expert (counselor) to individuals who have problems.

\section{Study Instruments}

The study instrument used for data collection was a questionnaire. Test the validity consists of content and face validity. Reliability testing in this study was conducted on 20 study subjects who conducted antenatal care at public health center in Kutai Kartanegara Regency area. Reliability testing is done by measuring variables using the SPSS 24 statistical program which can calculate total item correlations (200.20) and alpha Cronbach $(\geq 0.70)$.

\section{Data Analysis}

Univariate analysis was performed to see the frequency distribution and the percentage of the characteristics of the study subjects. Bivariate analysis was conducted to study the relationship between the incidence of diarrhea and independent variables using Pearson correlation test. Multivariate analysis was done using linear regression analysis models.

\section{Research Ethics}

The study ethics include informed consent, anonymity, confidentiality and ethical clearance. The ethical clearance in this study was conducted at the Medical Faculty of Sebelas Maret University with protocol number 01/18/10/319 which was published on October 24, 2018.

\begin{tabular}{l}
\hline RESULTS \\
\hline 1. Sample Characteristics \\
Table 1 showed that pregnant women with \\
light anxiety consist of 106 ( $53 \%)$, while \\
pregnant women with severe anxiety con- \\
sist of 94 (47\%). Pregnant women with low \\
education consist of 86 ( $43 \%)$, while \\
prenant women with higher education \\
consist of 114 ( $57 \%)$. Pregnant women with \\
a low family income consist of 61 (30.5\%), \\
while pregnant women with high family \\
income consist of 139 (69.5\%). Primiparous \\
pregnant women were 62 ( $31 \%)$, while \\
multiparous pregnant women consist of 138
\end{tabular}


(69\%). Pregnant women with weak family support of 77 (38.5\%), while those with strong family support are 123 (61.5\%). Pregnant women with mild stress consist of 85 (42.5\%), while stressed pregnant women consist of 115 (57.5\%). Pregnant women who have weak social interactions are 103 (51.5\%), while pregnant women who have strong social interactions are 97 (58.5\%). Pregnant women who rarely get counseling from health personnel consist of 57 (28.5\%), while pregnant women who often get counseling from health personnel are $143(71.5 \%)$.

Table 1. Sample Characteristics

\begin{tabular}{lcc}
\hline Variable & n & \% \\
\hline Anxiety & & \\
$\quad$ Light anxiety & 106 & 53 \\
$\quad$ Severe anxiety & 94 & 47 \\
Education & & \\
$\quad$ Low & 86 & 43 \\
$\quad$ High & 114 & 57 \\
Family Income & & \\
$\quad$ Low & 61 & 30.5 \\
$\quad$ High & 139 & 69.5 \\
Gravida & & \\
$\quad$ Primiparous & 62 & 31 \\
$\quad$ Multiparous & 138 & 69 \\
Family Support & & \\
$\quad$ Weak & 77 & 38.5 \\
$\quad$ Strong & 123 & 61.5 \\
Psychological stress & & \\
$\quad$ Light & 85 & 42.5 \\
$\quad$ Severe & 115 & 57.5 \\
Social interaction & & \\
$\quad$ Weak & 103 & 51.5 \\
$\quad$ Strong & 97 & 48.5 \\
Counseling & & \\
$\quad$ Seldom & 57 & 28.5 \\
$\quad$ Often & 143 & 71.5 \\
\hline
\end{tabular}

\section{Bivariate Analysis}

Bivariate analysis was used to find out the relationship of independent variables (edu- cation, gravida, employment status, family support, family income, psychological stress, social interaction and counseling) with the dependent variable (anxiety) which was analyzed by using the chi-square test using CI and significance level of $p$ $<0.05$. The results of the complete bivariate analysis can be seen in table 2 .

\section{Table 2. Bivariate Analysis}

\begin{tabular}{lccc}
\hline \multirow{2}{*}{$\begin{array}{c}\text { Independent } \\
\text { Variables }\end{array}$} & \multicolumn{3}{c}{ Anxiety } \\
\cline { 2 - 4 } & $\mathbf{n}$ & $\mathbf{r}$ & $\mathbf{p}$ \\
\hline Education & 200 & -0.35 & $<0.001$ \\
Family income & 200 & -0.20 & 0.006 \\
Gravida & 200 & -0.22 & 0.002 \\
Family support & 200 & -0.59 & $<0.001$ \\
Psychological & 200 & -0.53 & $<0.001$ \\
stress & & & \\
Social interaction & 200 & -0.54 & $<0.001$ \\
Counseling & 200 & -0.46 & $<0.001$ \\
\hline
\end{tabular}

Table 2 showed that there was a meaningful relationship between education and anxiety $\mathrm{p}<0.001$ and $\mathrm{r}=-0.35$, there was a meaningful relationship between family income and anxiety $\mathrm{p}<0.006$ and $\mathrm{r}=-0.19$, there was a meaningful relationship between gravida and anxiety $\mathrm{p}<0.002$ and $\mathrm{r}=-0.223$, there was a meaningful relationship between family support and anxiety $\mathrm{p}<0.001$ and $\mathrm{r}=-0.59$, there was a meaningful relationship between psychological stress and anxiety $\mathrm{p}<0.001$ and $\mathrm{r}=-0.53$, there was a meaningful relationship between social interaction and anxiety $\mathrm{p}<0.001$ and $\mathrm{r}=-0.54$ and there was a meaningful relationship between counseling and anxiety $\mathrm{p}<0.001$ and $\mathrm{r}=-0.46$.

\section{Multivariate Analysis}

Table 3. The Results of Linear Regression Analysis of Factors Affecting Anxiety for Pregnant Women in Labor 
Table 3. Multivariate Analysis

\begin{tabular}{|c|c|c|c|c|}
\hline \multirow{2}{*}{ Independent Variables } & \multirow[t]{2}{*}{ b } & \multicolumn{2}{|c|}{ CI (95\%) } & \multirow[t]{2}{*}{$\mathbf{p}$} \\
\hline & & Lower Limit & Upper Limit & \\
\hline Education & -2.37 & -3.93 & -0.81 & 0.003 \\
\hline Family income & -4.69 & -7.81 & -1.57 & 0.03 \\
\hline Gravida & -1.62 & -2.98 & -0.26 & $<0.001$ \\
\hline Family support & -0.38 & -0.52 & 0.24 & $<0.001$ \\
\hline Psychological stress & 0.33 & 0.16 & 0.49 & $<0.001$ \\
\hline Social interaction & $-0,27$ & -0.42 & $-0,12$ & $<0.001$ \\
\hline Counseling & -0.91 & -1.77 & $-0,05$ & 0.004 \\
\hline \multicolumn{5}{|l|}{$\mathrm{n}$ observation $=\mathbf{2 0 0}$} \\
\hline \multicolumn{5}{|l|}{ Adj R-Squared= } \\
\hline $\mathrm{p}<0.001$ & & & & \\
\hline
\end{tabular}

Table 3 showed that education $(b=-2.37$; 95\% CI $=-3.93$ to $-0.81 ; \mathrm{p}=0.003$ ), family income $(b=-4.69 ; 95 \% \mathrm{CI}=-7.81$ to $-1.57 ; \mathrm{p}=$ o.03), gravida $(\mathrm{b}=-0.38 ; 95 \% \mathrm{CI}=-2.98$ to $0.26 ; \mathrm{p}=0.001)$, family support $(\mathrm{b}=-0.38$; 95\% CI $=0.52$ to $0.24 ; \mathrm{p}=0.001$ ), psychological stress $(b=0.33 ; 95 \% \mathrm{CI}=0.16$ to 0.49 ; $\mathrm{p}=0.001)$, social interaction $(\mathrm{b}=-0.27 ; 95 \%$ $\mathrm{CI}=-0.42$ to $-0.12 ; \mathrm{p}=0.001)$ and counseling $(b=-0.91 ; 95 \% \mathrm{CI}=-1.77$ to-0.05; $\mathrm{p}=0.004)$

\section{DISCUSSION}

1. The relationship between education and anxiety among pregnant women

The results showed that there was a negative relationship between education and anxiety of pregnant women and it was statistically significant $(\mathrm{p}=0.003)$. The results of this study were in line with Nekoee and Zarei., (2015) which stated that there was a relationship between education and maternal anxiety, which the severe anxiety occurred in pregnant women with low education.

The result of this study was in line with Gao et al., (2015) which stated that there was a significant relationship $(\mathrm{p}=$ 0.025) between education and anxiety among pregnant women.

\section{The relationship between family income and anxiety among preg- nant women}

The results showed that there was a negative relationship between family income and anxiety of pregnant women and it was statistically significant (0.003). The result of this study was in line with a study done by Katz, et al., (2018) which stated that pregnant women with low income would not be able to fulfill their daily needs and prepare the equipment for the baby so that it was significantly related to the mental health of pregnant women.

The result of this study was in line with Nasreen et al.,(2011) which stated that low family income can increase the anxiety of pregnant women in facing labor.

\section{The relationship between gravida and anxiety among pregnant women}

The results showed that there was a negative relationship between the number of pregnancy and anxiety of pregnant women and it was statistically significant $(\mathrm{p}=$ o.001). The result of this study was in line with Madhavanprabhakaran et al., (2015) which stated that gravida has an impact on anxiety.

The result of this study was in line with Erkaya (2015) which stated that 
primiparous mothers were afraid to give birth because they did not have previous labor experience.

\section{The relationship between family support and anxiety among preg- nant women}

The results showed that there was a negative relationship between family support and anxiety of pregnant women and it was statistically significant. The result of this study was in line with Waqas et al., (2017) which stated that there was a significant relationship between support and anxiety. In this study, the score of $r$ was 0.43 for anxiety.

The result of this study was in accordance with Abdollahpour et al., (2015) which stated that family support with a pvalue of $<0.05$ show that there was a relationship of family support on the anxiety of pregnant women in facing labor.

\section{The relationship between psycho- logical stress and anxiety among pregnant women}

This study showed that there was a positive relationship between stress and anxiety which was statistically significant $(\mathrm{p}=$ o.001). This study was in line with Nisa et al. (2017) which stated that stress can increase anxiety in pregnant women $(b=$ $0.9201, \mathrm{SE}=0.01, \mathrm{p}<0.001)$.

\section{The relationship between social interaction and anxiety among pregnant women}

The results showed that there was a negative relationship between social interaction and anxiety of pregnant women and it was statistically significant.

The result of this study was in line with a study done by Jonsdottir et al., (2016), after a structured interview was conducted with 562 Icelandic women who were screened three times during pregnancy with the Anxiety Scale. From the number of respondents, 360 people have symptoms and women respond to weak social interactions during pregnancy.

\section{The relationship between coun- seling and anxiety among preg- nant women}

The results showed that there was a negative relationship between counseling and anxiety of pregnant women and it was statistically significant. The result of this study was in accordance with a study done Baghdari et al., (2018) which stated that there was an effect of counseling on anxiety. Study subjects who often got counseling from health personnels became aware of maternity information which in accordance with the circumstances of the study subjects

It can be concluded that the anxiety among pregnant women was affected by education, gravida, family support, family income, psychological stress, social interaction, and counseling.

\section{REFERENCES}

Bgahhdari N, Sahebzad ES, Kheirkhah M (2014). The effect of pregnancy adaptation training package on the anxiety of pregnant women with a prior history of fetal or neonatal death. J Midwifery Reprod Health. 2015; 3(2):355360

Chan CY, Lee AM, Lam SK, Lee CP, Leung KY, Koh YW, Tang K (2013). Antenatal anxiety in the first trimester: Risk factors and effects on anxiety and depression in the third trimester and. Open Journal of Psychiatry, 3: 301310. Doi: 10.4236/ojpsych. 2013. 330 30

Daglar G, Nur N (2014). The relationship between anxiety and depression levels and stress coping strategies of the pregnant women. Cumhuriyet Medicine Journal 36:429-441

Erkaya E, Karabulutlu O, Calik KY (2017) 
Defining Childbirth Fear And Anxiety Levels In Pregnant Women: Procedia Social and Behavioral Sciences 237 .

Gao LL, Liu X J, Fu, BL, Xie W (2015). Predictors of childbirth fear among pregnant Chinese women: A cross-sectional questionnaire survey. Midwifery, 31, 865-870. Doi: org/10. 1016/j.midw.201505.003

Health Office Kutai Kartanegara District (2016). Profil Kesehatan Kabupaten Kutai Kartanegara. Dinas Kesehatan Kabupaten Kutai Kartanegara

(2017). Profil Kesehatan Kabupaten Kutai Kartanegara. Dinas Kesehatan Kabupaten Kutai Kartanegara

Health Office East Kalimatan Province (2017). Profil Kesehatan Provinsi Kalimantan Timur. Dinas Kesehatan Provinsi Kalimantan Timur

Halgin RP, Whitebourne SK (2010). Psikologi abnormal. Salemba Humanika: Jakarta.

Jonsdottir SS, Thome M, Steingrimsdottir T, Lydsdottir LB, Sigurdsson JF, Olafsdottir H, Swahnberg K (2016). Partner Relationship, Social Support and Perinatal Distress Among Pregnant Icelandic Women. Doi: org/10.1016/j.wombi.2016.08.0051871-5192/ã 2016 Australian College of Midwives.

Ministry of Health Republik Indonesia (2013). Riset Kesehatan Dasar. Badan Penelitian dan Pengembangan Kesehatan Kementerian Kesehatan RI

(2017). PMK RI Nomor 39 tahun

2016 tentang pedoman penyelenggaraan program Indonesia Sehat dengan pendekatan keluarga Jakarta: Kementerian Kesehatan RI.

(2016). Profil Kesehatan Indonesia. Jakarta: Kementerian Kesehatan RI

Mandagi DVV, Pali C, Sinolungan JSV
(2013). Perbedaan Tingkat Kecemasan Pada Primigravida dan Multigravida di RSIA Kasih Ibu Manado. Jurnal eBiomedik (eBM). 1 (1): 197-201.

Murti B (2018). Prinsip dan Metode Riset Epidemiologi. Edisi II.Cetakan I. Program Studi Ilmu Kesehatan Masyarakat, Program Pascasarjana, Universitas Sebelas Maret. Surakarta

Nasreen HE, Kabir ZN, Forsell Y, Edhborg $M$ (2011). Prevalence and associated factors of depressive and anxiety symptoms during pregnancy: A population based study in rural Bangladesh. BMC Women's Health, 11, 22. Doi: org/http://dx.doi.org/10.1186/1472-6874-1122.

Nekoee T, Zarei M (2015). Evaluation the Anxiety status of pregnant women in third trimester of pregnancy and fear of childbirth and related factors. British Journal of Medicine \& Medical Study. 9(12): 1-8.

Nisa SMK, Murti B, Qadrijati I (2018). Path analysis on the psichosicial factors afeecting anxiety and delivery pain.

Rayment JH (2017). A multisite audit to assess how women with complex social factors access and engage with maternity services, Midwifery. Doi: 10.1016/j.midw.2017.06.004

Walyani ES (2017). Asuhan kebidanan pada kehamilan. Yogyakarta: PT. Pustaka Baru.

Waqas A, Raza N, Lodhi HW, Muhammad Z, Jamal M, Rehman A (2015). Psychosocial factors of antenatal anxiety and depression in Pakistan: Is social support a mediator? PLoS ONE, 10(1), 1-14. https://doi.org/10.1371/journal.pone.0116510

WHO (2015).World Report on Ageing and Health. Geneva: WHO. 